\title{
Hydrogenation of Maltose in Catalytic Membrane Reactor for Maltitol Production
}

\author{
I.G.B.N. Makertihartha ${ }^{1}$, Khoiruddin ${ }^{1}$, Ahmad N. Hakim ${ }^{1}$, P.T.P. Aryanti ${ }^{2}$, and I.G. Wenten ${ }^{1, *}$ \\ ${ }^{1}$ Chemical Engineering Department, Institut Teknologi Bandung, Jalan Ganesha 10, Bandung 40132, Indonesia \\ ${ }^{2}$ Chemical Engineering Department, Universitas Jenderal Achmad Yani, J1. Ters. Jend. Sudirman, Cimahi 40285, Indonesia
}

\begin{abstract}
Maltitol is one of the low-calorie sweeteners which has a major role in food industries. Due to its characteristics of comparable sweetness level to sucrose, maltitol can be a suitable sugar replacement. In this work, catalytic membrane reactor (CMR) was examined in maltitol production through hydrogenation of maltose. Commercial ceramic membrane impregnated with Kalcat 8030 Nickel was used as the CMR. The reaction was conducted at a batch mode operation, 95 to $110^{\circ} \mathrm{C}$ of temperature, and 5 to 8 bar of pressure. In the range of working conditions used in this study, up to $47 \%$ conversion was achieved. The reaction conversion was significantly affected by temperature and pressure. Results of this preliminary study indicated that CMR can be used for hydrogenation of maltose with good performance under a relatively low operating pressure.
\end{abstract}

\section{Introduction}

Low calorie sweetener usage shows a significant increase recently. This is due to an improved paradigm in order to achieve a healthy lifestyle. Maltitol is one of these calorie sweetener that has a major role in food industry. Since maltitol has a comparable characteristic and sweetness level to sucrose, it makes maltitol suitable as sugar replacement. Moreover, maltilol can be used as an intermediate product for pharmaceuticals industry [1].

Generally, maltose hydrogenation is carried out in a batch slurry reactor. Studies on hydrogenation reactions of maltose in conventional batch slurry reactors can be found in literature [1-8]. The drawback of this conventional reactor is a poor contact between reactant and catalyst. Therefore, a high operating pressure, e.g. 20-30 bar, is usually used. Consequently, it usually requires a relatively high investment cost due to system complexity. This necessitates the improvement of hydrogenation reactor to overcome the gas-liquid interface constraint as well as to simplify the hydrogenation reaction design.

Nowadays, membrane technology is used in almost industrial processes and starts to replace the competing conventional technologies due to its interesting features [9-19]. Membrane offers the advantages of relatively lower foot print, lower cost, easy to scale-up, and more energy intensive [20-23]. Membrane also provides a possibility to combines a several steps or processes into a hybrid process thus an intensified process can be obtained [24-29]. CMR is a hybrid membrane process which facilitates catalytic reaction and contact between reactants. CMR was used by several studies to replace the conventional hydrogenation reactor. Veldsink [30] used CMR for hydrogenation of sunflower seed oil. The hydrogenation reaction was not affected by interfacial transport resistance and intraparticle diffusion limitation. Bottino et al [31] reported a study of hydrogenationisomeration of methylenecyclohexane in a CMR and compared with the conventional reactor. They also found that the hydrogenation reaction in a catalytic membrane reactor was controlled by kinetic regime and thus the reaction conversion could be increase while avoiding the high pressure operation. In this work, performance of $\mathrm{CMR}$ in hydrogenation of maltose is investigated. A ceramic membrane is used as CMR and commercial nickel catalyst is impregnated in the membrane pores. The effect of temperature and pressure on reaction conversion is analyzed and discussed.

\section{Materials and method}

Maltose used in this study has a $60^{\circ}$ Brix concentration. Kalcat 8030 Nickel was used as catalyst. Technical grade citric acid and demineralized water were used to prepare catalyst suspension. High purity hydrogen $(99.9 \%)$ was used in hydrogenation reaction. Tubular ceramic membrane was used as membrane reactor $\left(\mathrm{Al}_{2} \mathrm{O}_{3}, 100 \mathrm{kDa}\right.$ MWCO, 19 channels, $4 \mathrm{~mm}$ inside diameter, and $0.3 \mathrm{~m}$ length).

Experimental set up for catalyst impregnation and hydrogenation reaction are shown in Fig. $1 \mathrm{a}$ and b. Catalyst impregnation was conducted by circulating catalyst suspension which contained $25 \mathrm{~g}$ catalyst in 500 $\mathrm{mL}$ citric acid solution (20\%). After circulation, the membrane was drying in oven at $80^{\circ} \mathrm{C}$ for $6 \mathrm{~h}$ and then calcinated at $200^{\circ} \mathrm{C}$ for $3 \mathrm{~h}$. Hydrogenation was

\footnotetext{
Corresponding author: igw@che.itb.ac.id
} 
conducted for $6 \mathrm{~h}$ at various operating temperatures and pressures. Between each reaction, membrane module was flush with demineralized water. Subsequently, the membrane was flushed with nitrogen. Every $45 \mathrm{~min}$. reduced sugar content was analyzed by Eynon-Lane titration method in Ref. [32].
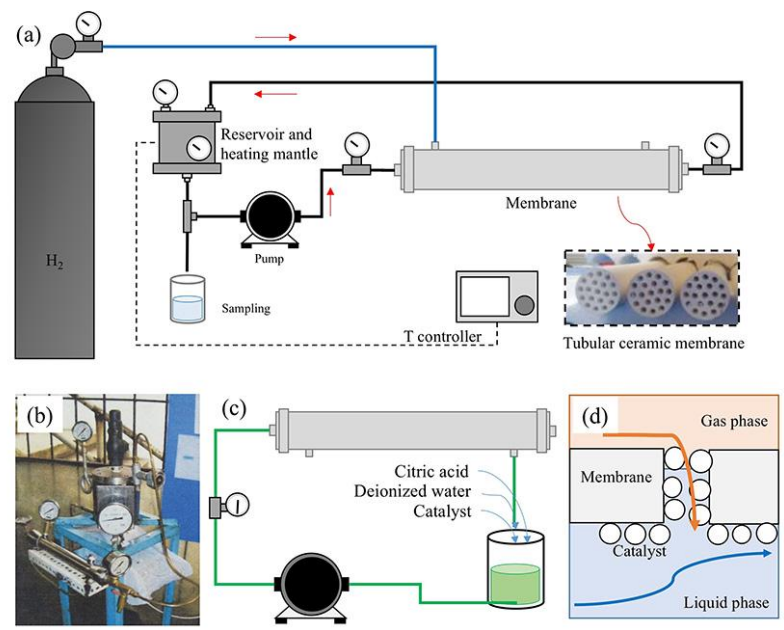

Fig. 1. Experimental set up. (a) Schematic of CMR, (b) photograph of experimental set up, (c) catalyst impregnation, and (b) hydrogenation reaction in CMR.

\section{Results and discussion}

The effect of temperature and pressure on hydrogenation reaction conversion and profile are shown in Fig. 2 (a) to (b). It can be observed that both operating parameters have the significant effect on hydrogenation reaction conversion. Temperature is one of the parameters that influence the kinetic rate. As the temperature increases, the reaction rate is increased. Operating pressure has a similar effect on reaction conversion. The reaction conversion increases with the increase of pressure. A drastic increase of reaction conversion is observed from 5 to 6 bar. It may be due to the minimum reaction condition was not achieved at 5 bar. In addition, it can be observed that reaction conducted at 6 bar has a conversion reaction which closes to that at 8 bar. It may be implied that contact between the multiple phases of reactants in the catalytic membrane reactor is good enough and no more depended on the dispersion of gas phase in the reactants mixture.

Reaction scheme, $\mathrm{C} / \mathrm{Co}$, reaction conversion at various reaction time at 6 bar and $110^{\circ} \mathrm{C}$ can be observed in Fig. 3. According to the reaction scheme, the $\mathrm{n}^{\text {th }}$-order reaction rate equation can be writen as $\mathrm{I}=d C / d t=-k C^{n}$. By assuming that the reaction rate follows the first order mechanism $(n=1)$, the integration of the reaction rate will result in a linear correlation between $\ln (\mathrm{C} / \mathrm{Co})$ and $t$ with the slope of the linear plot is the negative value of rate constant, $-k$. Linear regression of the experimental $\ln (\mathrm{C} / \mathrm{Co})$ vs $t$ plot gives high $R$-square value of $95.13 \%$ and the rate constant of the hydrogenation reaction, $k$, can be estimated to be $3.3 \times 10^{-5} \mathrm{~s}^{-1}$. The high $R$-square value proves that the assumption of first order mechanism is satisfied. (a)

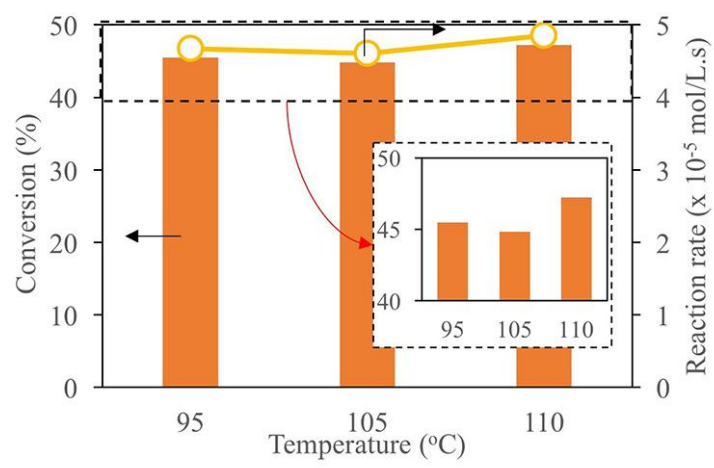

(b)

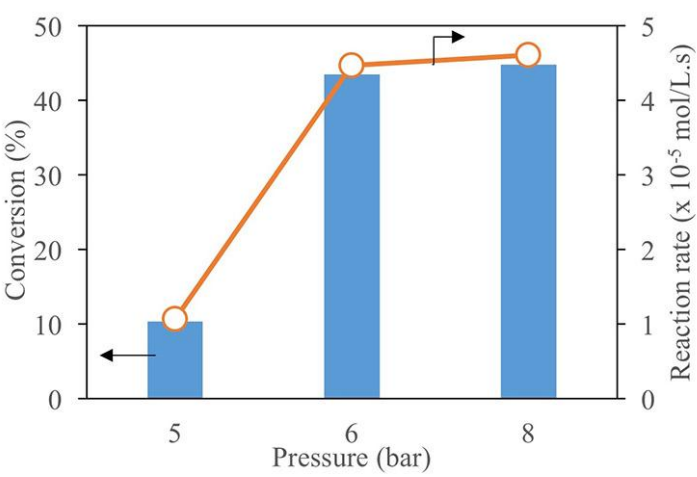

Fig. 2. Reaction conversion and reaction rate at various temperature $\left(\mathrm{a}\right.$; at 8 bar) and pressure $\left(\mathrm{b}\right.$; at $\left.110^{\circ} \mathrm{C}\right)$.

(a)

$$
\mathrm{C}_{12} \mathrm{H}_{22} \mathrm{O}_{11} \underset{\text { catalyst }}{\stackrel{\mathrm{H}_{2}}{\rightarrow}} \mathrm{C}_{12} \mathrm{H}_{24} \mathrm{O}_{11}
$$

(b)

(c)
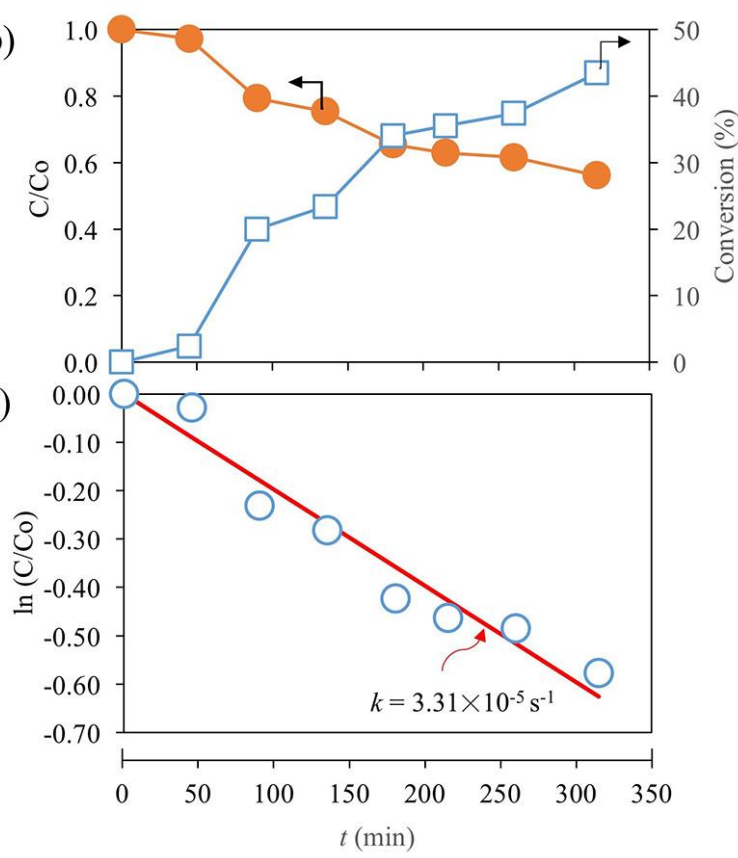

Fig. 3. (a) Reaction scheme of maltose hydrogenation, (b) $\mathrm{C} / \mathrm{Co}$ vs $\mathrm{t}$ (at 8 bar and $110^{\circ} \mathrm{C}$ ), and (c) $\ln \mathrm{C} / \mathrm{Co}$ vs $\mathrm{t}$ (at 6 bar and $110^{\circ} \mathrm{C}$ ).

In a conventional reactor, a high hydrogen pressure is usually used to overcome the mass-transfer or diffusion limitation in a three-phase mixture. In this study, at a maximum pressure of 8 bar, reaction conversion of $47 \%$ 
can be obtained. Even at lower pressure, 6 bar, the conversion is almost similar. This operating pressure is far below the operating pressure that usually used in conventional reactors (see Table 1). The reaction rate is also higher compared to the conventional reactors. According to Bottino et al [31], hydrogenation in catalytic membrane reactor offers a better control on operating condition rather than the conventional slurry bath reactor since the reaction is only a kineticcontrolled regime. Meanwhile, for in conventional reactor, the diffusion-controlled regime was also observed. Benefiting from its better diffusion and contact between hydrogen gas, liquid maltose, and solid catalyst, catalytic membrane reactor requires a relatively low hydrogen pressure to achieve a high conversion reaction. In addition, the reaction rate can be increased further by increasing the reaction temperature. This is expected to reduce the complexity of the reactor unit as well as the investment cost.

Table 1. Conversion of maltose hydrogenation from several reported studies

\begin{tabular}{|c|c|c|c|}
\hline $\begin{array}{c}\text { Operating } \\
\text { conditions }\end{array}$ & $\begin{array}{c}\text { Reactor; } \\
\text { Catalyst }\end{array}$ & Conv. (\%) & Ref. \\
\hline $\begin{array}{c}50 \mathrm{~mL} ; 40 \% \text {-wt. } \\
\text { maltose; } 30 \text { bar; } \\
120^{\circ} \mathrm{C} ; 4 \mathrm{~h} .\end{array}$ & $\begin{array}{c}\text { Slurry batch; } \\
\text { Co-B }\end{array}$ & 33.7 & {$[1]$} \\
\hline $\begin{array}{c}50 \mathrm{~mL} ; 40 \% \text {-wt. } \\
\text { maltose; } 20 \text { bar; } \\
90^{\circ} \mathrm{C} ; 2 \mathrm{~h} .\end{array}$ & $\begin{array}{c}\text { Slurry batch; } \\
\text { Ni-P }\end{array}$ & 17.2 & {$[7]$} \\
\hline $\begin{array}{c}50 \mathrm{~mL} ; 40 \% \text {-wt. } \\
\text { maltose; } 30 \text { bar; } \\
100^{\circ} \mathrm{C} ; 50 \text { min. }\end{array}$ & $\begin{array}{c}\text { Slurry batch; } \\
\text { Raney Ni }\end{array}$ & 5.2 & {$[8]$} \\
\hline $\begin{array}{c}50 \mathrm{~mL} ; 40 \% \text {-wt. } \\
\text { maltose; } 30 \text { bar; } \\
100^{\circ} \mathrm{C}, 3 \mathrm{~h} .\end{array}$ & $\begin{array}{c}\text { Slurry batch; } \\
\text { Ru-B-C }\end{array}$ & 73 & {$[2]$} \\
\hline $\begin{array}{c}50 \mathrm{~mL} ; 40 \% \text {-wt. } \\
\text { maltose; } 30 \text { bar, } \\
100^{\circ} \mathrm{C} ; 0.5 \mathrm{~h} .\end{array}$ & $\begin{array}{c}\text { Slurry batch; } \\
\text { Raney Ni }\end{array}$ & 2 & {$[6]$} \\
\hline $\begin{array}{c}600 \mathrm{~mL} ; 60 \% \text {-wt } \\
\text { maltose; } 6 \text { bar; } \\
110^{\circ} \mathrm{C} ; 6 \mathrm{~h} .\end{array}$ & $\begin{array}{c}\text { CMR; Kalcat } \\
8030 \mathrm{Ni}\end{array}$ & 47.2 & $\begin{array}{c}\text { This } \\
\text { work }\end{array}$ \\
\hline
\end{tabular}

In catalytic membrane reactor, reaction occurs only when the solution contacts with catalyst inside the membrane phase. Meanwhile, during the circulation (in the reservoir and in piping), reaction does not occur. This is one of the disadvantages of CMR compared to slurry reactor batch. Therefore, it is suggested to use a cascade membrane system in order to minimize the inactive reaction time.

\section{Conclusions}

In this work, catalytic membrane reactor (CMR) was examined in maltitol production through hydrogenation of maltose. Commercial ceramic membrane impregnated with Kalcat 8030 Nickel was used as the CMR. The reaction was conducted at a batch mode operation, 95 to $110^{\circ} \mathrm{C}$ of temperature, and 5 to 8 bar of pressure. In the range of working conditions used in this study, up to $47 \%$ conversion was achieved. The reaction conversion was significantly affected by temperature and pressure. Results of this preliminary study indicated that CMR can be used for hydrogenation of maltose with a good performance under a relatively low operating pressure.

\section{References}

1. H. Li, P. Yang, D. Chu, H. Li, Appl. Catal. A Gen., 325, 34 (2007).

2. H. Li, Y. Wang, Q. Zhao, H. Li, Res. Chem. Intermed., 35, 779 (2009).

3. D. Chu, H. Li, H. Li, Shiyou Huagong/Petrochemical Technol., 35, 1125 (2006).

4. E.M. Sulman, M.E. Grigorev, V.Y. Doluda, J. Wärnå, V.G. Matveeva, T. Salmi, D.Y. Murzin, Chem. Eng. J., (2015).

5. Y. Ren, W. Li, Y. Han, M. Zhang, K. Tao, Shiyou Huagong/Petrochemical Technol., 37, 29 (2008).

6. Y. Wang, L. Xu, L. Xu, H. Li, H. Li, Cuihua Xuebao/Chinese J. Catal., 34, 1027 (2013).

7. H. Li, D. Chu, J. Liu, M. Qiao, W. Dai, H. Li, $A d v$. Synth. Catal., 350, 829 (2008).

8. Q. Meng, H. Li, H. Li, J. Phys. Chem. C, 112, 11448 (2008).

9. K. Khoiruddin, A.N. Hakim, I.G. Wenten, Membr. Water Treat., 5, 87 (2014).

10. N.F. Himma, S. Anisah, N. Prasetya, I.G. Wenten, J. Polym. Eng., 36, 329 (2016).

11. M. Purwasasmita, D. Kurnia, F.C. Mandias, Khoiruddin, I.G. Wenten, Food Bioprod. Process., 94, 180 (2015).

12. D. Ariono, M. Purwasasmita, I.G. Wenten, J. Eng. Technol. Sci., 48, 367 (2016).

13. D. Ariono, Khoiruddin, Subagjo, I.G. Wenten, Mater. Res. Express, 4, 24006 (2017).

14. P.T.P. Aryanti, R. Yustiana, R.E.D. Purnama, I.G. Wenten, Membr. Water Treat., 6, 379 (2015).

15. I.N. Widiasa, P.D. Sutrisna, I.G. Wenten, Sep. Purif. Technol., 39, 89 (2004).

16. Khoiruddin, I.N. Widiasa, I.G. Wenten, J. Food Eng., 133, 40 (2014).

17. Khoiruddin, D. Ariono, Subagjo, I.G. Wenten, J. Appl. Polym. Sci., (2017).

18. N.F. Himma, A.K. Wardani, I.G. Wenten, Mater. Res. Express, 4, 54001 (2017).

19. P.T.P. Aryanti, M. Sianipar, M. Zunita, I.G. Wenten, Membr. Water Treat., 8, 463 (2017).

20. I.G. Wenten, P.T. Dharmawijaya, P.T.P. Aryanti, R.R. Mukti, Khoiruddin, RSC Adv., 7, 29520 (2017).

21. I.G. Wenten, Khoiruddin, Desalination, 391, 112 (2016).

22. I.G. Wenten, Khoiruddin, F. Arfianto, Zudiharto, Desalination, 314, 109 (2013).

23. A.K. Wardani, A.N. Hakim, Khoiruddin, I.G. Wenten, Water Sci. Technol., 75, 2891 (2017).

24. M. Purwasasmita, E.B.P. Nabu, Khoiruddin, I.G. Wenten, J. Eng. Technol. Sci., 47, 426 (2015).

25. I.G. Wenten, H. Julian, N.T. Panjaitan, Desalination, 306, 29 (2012).

26. I.G. Wenten, I.N. Widiasa, Desalination, 149, 279 
(2002)

27. I.G.B.N. Makertihartha, P.T. Dharmawijaya, M. Zunita, I.G. Wenten, Adv. Sci. Lett., 23, 5726 (2017).

28. A.N. Hakim, Khoiruddin, I.G. Wenten, Adv. Sci. Lett., 23, 5640 (2017).

29. I.G. Wenten, Khoiruddin, N.F. Himma, $A d v$. Sci. Lett., 23, 5768 (2017).

30. J.W. Veldsink, J. Am. Oil Chem. Soc., 78, 443 (2001).

31. A. Bottino, G. Capannelli, A. Comite, A. Del Borghi, R. Di Felice, Sep. Purif. Technol., 34, 239 (2004).

32. C.A. Browne, F.W. Zerban., Physical and chemical methods of sugar analysis: a practical and descriptive treatise for use in research, technical, and control laboratories, 3rd ed., J. Wiley \& sons, inc., New York (1941). 